\title{
CONFLICTS OF JURISDICTION IN THE ANTITRUST FIELD: THE EXAMPLE OF EXPORT CARTELS
}

\author{
James R. Atwood*
}

\section{INTRODUCTION}

If today's furor over jurisdictional conflicts was not born in the field of antitrust law, surely that is where it matured. National differences in attitude and policy toward cartels and antitrust are deep and widespread. What may be one country's chosen instrument to gain hard currency might be condemned by another as an exploitative monopoly or trust. As Lord Wilberforce observed, "[i]t is axiomatic that in anti-trust matters the policy of one state may be to defend what it is the policy of another state to attack."1

This symposium exposes the fascinating diversity of jurisdictional conflicts found in today's world of complex and highly interdependent economies. In the face of that diversity, it is instructive that even the simple, classic case of the export cartel continues to defy clear legal rules. If legal systems, both domestic and international, are unable to develop workable and predictable guidelines for the application of national antitrust laws to export cartels, what are the chances that more complex and multifaceted disputes can be satisfactorily addressed by lawyers, courts, or even governments?

The United States must assume principal responsibility for the unsettled state of the law on export cartels. United States courts, urged on by the Department of Justice, took the first bold steps to have national antitrust laws applied to offshore consortia. Government enforcement actions such as Alcoa in the 1940's, ${ }^{2}$ Swiss Watchmakers in the 1960's, ${ }^{3}$ and the Uranium Antitrust Litigation in the $1970{ }^{\prime} \mathrm{s}^{4}$ raised jurisdictional problems in stark, practical terms. Met with diplomatic protests, the United States then took steps to retrench on the reach of its law, but the retrenchment has been so ad hoc and case-by-case

Copyright $@ 1988$ by Law and Contemporary Problems

* Partner, Covington \& Burling, Washington, D.C.

1. Rio Tinto Zinc Corp. v. Westinghouse Elec. Corp., 1 All E.R. 434, 448 (1978).

2. United States v. Aluminum Co. of Am., 148 F.2d 416 (2d Cir. 1945).

3. United States v. Watchmakers of Switz. Info. Center, 1963 Trade Cas. (CCH) ๆ 70,600 (S.D.N.Y.), judgment modified, 1965 Trade Cas. (CCH) I 71,352 (S.D.N.Y. 1962).

4. See United States v. Gulf Oil Corp., Crim. No. 78-123 (E.D. Pa. filed May 9, 1978). Ultimately, the civil uranium suits proved to be far more contentious than the rather limited government action. See Uranium Antitrust Litig., 617 F.2d 1248 (7th Cir. 1980). For a brief history of the litigation, see $1 \mathrm{~J}$. ATwood \& K. Brewster, Antitrust and American Business Abroad $\$ 6.16$ (2d ed. 1981). 
in nature that principles of clarity, fairness, and predictability are at risk. At times one is left with the uneasy feeling that U.S law extends to foreign cartels to the extent-but only to the extent-that the Administration in power can take the heat. Obviously, a more principled rule of law is preferable, and surely the business executive and his counselor would hope for a rule that was more useful for the long-range planning needed in today's business world.

Because the American legal rules are in the center of the extraterritoriality debate, this article focuses initially on how U.S. law addresses export cartels. First, how does the United States treat its own export cartels? Second (and more importantly for present purposes), how does it treat the export cartels of others? Finally, this article suggests ways to add greater clarity and fairness to the existing law and, perhaps at the same time, ways to reduce the degree of jurisdictional conflict that current law seems to invite.

\section{II}

\section{Export Cartels: A Definition}

The term "export cartel" is not entirely self-defining. The simplest case is what some have called the "pure export cartel," generally used to refer to a cartel composed of a group of producers within a single country whose collaborative conduct is directed solely at foreign markets. A "mixed export cartel," by comparison, is also a national (single-country) cartel, but one that has some domestic as well as foreign commercial effects. An "international export cartel" is generally defined as one with exporters from more than a single country. ${ }^{5}$

When using the phrase "export cartel," this article will be referring to the "pure export cartel"- exporters from a single country. In a few instances, though, the analytical differences presented where the cartel has domestic as well as foreign effects and where the cartel takes on a multinational character will be considered.

\section{III}

\section{The American Approach to U.S. Export Cartels}

Virtually every nation has laws or policies that permit export cartels to operate from within its borders. ${ }^{6}$ The United States is no different. Indeed, America's tolerance for its own export cartels is almost as old as its antitrust laws. The 1918 Webb-Pomerene $\mathrm{Act}^{7}$ was avowedly a license for U.S. exporters to band together to exercise their collective bargaining power in foreign markets. The justification at the time was that small U.S. firms needed mutual support to counter the economic power of dominant foreign buying

5. See generally Report of the [OECD] Committee of Experts on Restrictive Business Practices, Export Cartels 7 (1974) [hereinafter Report of the OECD Committee].

6. See, e.g., Report of The OECD Committee, supra note 5, at 8-21.

7. 15 U.S.C. $\$ \S 61-66$ (1982). For a fuller discussion and collection of citations to secondary authorities, see $1 \mathrm{~J}$. ATwood \& K. BREwster, supra note 4, §§ 2.10, 9.35-9.46. 
cartels. ${ }^{8}$ The statute, however, was drafted in broad terms and hence is confined neither to small companies nor to situations fitting its original rationale of countervailing power.

Other limitations of the Webb-Pomerene Act, however, have severely limited its usefulness to U.S. exporters and hence its impact on foreign markets. As stated recently by Senator Lloyd Bentsen, the Act is "so confusing, dated, and ambiguous that it actually discourages the formation of U.S. consortia."'9 Services and technology licensing are not covered by the act; ${ }^{10}$ no domestic commerce whatever may be involved; ${ }^{11}$ and the availability of an antitrust exemption under U.S. law is resolved entirely on an ex post facto basis with treble damages or conceivably even a prison term awaiting the exporter who guesses incorrectly. It is no wonder that the Webb-Pomerene Act has played only a very minor role in U.S. export trade over the years. ${ }^{12}$

Congress revisited the subject of American export cartels in 1982 and again gave them at least a qualified blessing. The Export Trading Company $\mathrm{Act}^{13}$ of that year reflected a congressional concern that the U.S. antitrust laws were inhibiting American exports and that some courts, in applying the Sherman Act, had lost sight of the important national interest of export promotion. In the 1982 statute, Congress tried to convey the following basic message (one to which the Justice Department had already subscribed ${ }^{14}$ ): The U.S. antitrust laws exist for the protection of American and not foreign interests. Where export activities have an adverse competitive effect on U.S. interests-such as by restricting imports through collateral agreements, facilitating restrictions on domestic trade, or blocking export efforts by U.S.based competititors-U.S. laws should be applied with full force. Where, however, restrictive export arrangements are directed and have their impact only on foreign markets, they are not a matter of U.S. antitrust concern. Indeed, such arrangements may be in the national interest. In short, the United States should not apply its national laws to its own export cartels. ${ }^{15}$

8. See Federal Trade Commission, Report on Cooperation in American Export Trade 372 75 (1916).

9. 126 ConG. ReC. 1451 (1980).

10. 15 U.S.C. $\$ 61$ (1982) ("export trade" means "solely" trade in "goods, wares, or merchandise"). See also Antitrust Division, U.S. Dep't of Justice, ANTitrust Guide for INTERNATIONAL OPERATIONS 4 (1977).

11. 15 U.S.C. $\$ 62$ (1982) (Webb-Pomerene associations must be engaged "solely" in export trade).

12. Studies in 1967 and 1976 indicated that Webb-Pomerene associations accounted for only two or three percent of U.S. export trade. Federal Trade Commission, Webb-Pomerene Associations: Ten Years later 15 (1978) (staff report); Federal Trade Commission, WebbPomerene Associations: A 50-Year Review 24, 33-34 (1967) (staff report).

13. Pub. L. No. 97-290, 96 Stat. 1233 (codified as amended at 15 U.S.C. $\$ \$ 4001-4021$ (1982)). For a collection of applicable regulations, forms, and a bibliography, see U.S. DeP'T of CommerCE, Export Trading Companies: A Handbook for Professionals (1985).

14. See Antitrust Guide for International Operations, supra note 10, at 4-5.

15. For the most pertinent legislative history, see S. REP. No. 27, 97th Cong., lst Sess (1982); H.R. ReP. No. 686, 97 th Cong., 2d Sess. (1982); H.R. ReP. No. 924, 97th Cong., 2d Sess. (1982) (conference report). 
In typical American fashion, this basic point required statutory language of considerable complexity. Indeed, a new administrative apparatus had to be created. Under one part of the statute, exporters are invited to apply to the Commerce and Justice Departments for "certificates of review," a form of governmental clearance that affords considerable protection against both private and government antitrust attacks for whatever proposed export conduct is specified in the certificate. ${ }^{16}$ An alternative form of protection found in another part of the statute redefines the jurisdictional reach of the Sherman and Federal Trade Commission Acts to preclude their application to wholly foreign-directed conduct. ${ }^{17}$ While to date the impact of the 1982 statute has been slight, ${ }^{18}$ it should give some comfort to U.S. industry as it considers possible forms of collaborative export conduct.

Note that the 1982 Act, like the Webb-Pomerene Act before it, implicitly rejects the economic theorizing found in some early antitrust decisions, where courts rejected the notion that export cartels can benefit the national economy. An example is Judge Wyzanski's 1950 Minnesota Mining opinion. ${ }^{19}$ There the government successfully challenged various joint export efforts by a dominant group of U.S. companies in the coated abrasives industry. One of the defendants argued that their joint efforts, including the operation of jointly-owned foreign plants, enhanced the profitability of their foreign sales, which-they argued-was "in the interest of American enterprise." Judge Wyzanski rejected the argument, concluding that any restriction on U.S. exports was against the national interest as embodied in the Sherman Act, even if on a restricted basis export trade became more profitable. His point seemed to be that it was more important to achieve competition in export trade and to maximize the flow of our export commerce, even if-as a resultexport trade became less profitable for the particular companies involved. ${ }^{20}$

Arguably, Judge Wyzanski was not making an economic argument about the virtues or lack of virtues of export cartels. His point, instead, may have been that a judge is simply not entitled to listen to economic arguments where they appear to take issue with the pro-competitive mandate of the antitrust laws. Such arguments, Judge Wyzanski would say, should be directed to

16. 15 U.S.C. $\$ \S 4011-4021$ (1982).

17. 15 U.S.C. $\$ \S 6 a, 45(a)(3)$ (1982). See Papst Motoren v. Kanematsu-Gosho, Inc., 1986-1 (CCH) Trade Cas. I 66,924 (S.D.N.Y.); Eurim-Pharm v. Pfizer Inc., 593 F. Supp. 1102 (S.D.N.Y. 1984).

18. See, e.g. U.S. General Accounting Office, Export Promotion: Implementation of the Export TRading Company ACT of 1982 (1986).

19. United States v. Minnesota Mining \& Mfg. Co., 92 F. Supp. 947 (D. Mass. 1950).

20. Judge Wyzanski wrote:

Financial advantage is a legitimate consideration for an individual non-monopolistic enterprise. It is irrelevant where the action is taken by a combination and the effect, while it may redound to the advantage of American finance, restricts American commerce. For Congress in the Sherman Act has condemned whatever unreasonably restrains American commerce regardless of how it fattens profits of certain stockholders. Congress has preferred to protect American competitors, consumers and workmen.

92 F. Supp. at 962 . For similar language, see Justice Black's dictum in Timken Roller Bearing Co. v. United States, 341 U.S. 593, 599 (1951). 
Congress. Today, American judges feel more at liberty to assess economic arguments, even where they cut against antitrust claimants. ${ }^{21}$ But, in any event, Congress appears to have accepted in the 1982 statute the economic view that as a nation we should seek to optimize the terms, rather than simply the volume, of our export trade. That, of course, is a philosophy that OPEC and others have practiced for a long time.

\section{IV}

\section{The American Approach to Foreign Export Cartels}

The other side of the coin involves an examination of how the American legal system views foreign export cartels. The answer is complex, and this article will present only a summary picture.

Certainly the classic American position was that a foreign cartel whose activities had a direct, substantial, and reasonably foreseeable effect on American commerce was fully subject to U.S. antitrust laws. ${ }^{22}$ The fact that the conduct occurred abroad ${ }^{23}$ or was sanctioned by a foreign host government ${ }^{24}$ created no defense. Whether in practice the U.S. authorities vigorously and routinely prosecuted foreign export cartels is another question. The "police dogs from the antitrust division,"'25 as Dean Acheson liked to call them, did in fact temper their prosecutorial zeal, especially when important foreign-policy interests were at stake. ${ }^{26}$ However, the government always maintained the theoretical right to apply U.S. law in a virtually unfettered manner to foreign export cartels impacting on the United States.

Today the U.S. position has shifted, but exactly how much is difficult to say. The American legal system, together with its antitrust enforcement agencies, now generally subscribes to the new "jurisdictional rule of reason." 27 This is an important but elusive concept, bearing many similarities

21. See, e.g., Matsushita Elec. Indus. Co. v. Zenith Radio Corp., 106 S.Ct. 1348 (1986); Continental T.V. Inc. v. GTE Sylvania Inc., 433 U.S. 36 (1977).

22. See United States v. Aluminum Co. of Am., 148 F.2d 416 (2d Cir. 1945).

23. See, e.g., Antitrust Guide for International Operations, supra note 10, at 6. The Guide states:

[T]he U.S. antitrust laws ... are not limited to transactions which take place within our borders. When foreign transactions have a substantial and foreseeable effect on U.S. commerce, they are Id. at 6 .

subject to U.S. law regardless of where they take place.

24. See, e.g., United States v. Watchmakers of Switz. Info. Center, 1963 (CCH) Trade Cas. $\S 70,660$, at $77,456-57$ (S.D.N.Y. 1962) ("The fact that the Swiss Government may, as a practical matter, approve of the effects of this private activity cannot convert what is essentially a vulnerable private conspiracy into an unassailable system resulting from governmental mandate.").

25. D. Acheson, Present at the Creation 682 (1969).

26. For an example of the international petroleum cartel case of the 1940's and 1950's, see $1 \mathrm{~J}$. ATwood \& K. BREWSTER, supra note $4, \S 2.24$.

27. Timberlane Lumber Co. v. Bank of Am., 549 F.2d 597, 613 (9th Cir. 1976). See also Montreal Trading Ltd. v. Amax Inc., 661 F.2d 864 (10th Cir. 1981); Mannington Mills, Inc. v. Congoleum Corp., 595 F.2d 1287 (2d Cir. 1979); Restatement (Revised) of Foreign Relations LAW of The United States \$ 416 (Tent. Draft No. 6, 1985); Meessen, Antitrust Jurisdiction under Customary International Law, 78 AM. J. INT'L L.. 783 (1984); Gill, Two Cheers for Timberlane, 10 Swiss Rev. Int'l Competition L. 3 (1980). The “jurisdictional rule of reason" phrase originated in $\mathrm{K}$. Brewster, Antitrust and American Business Abroad 446 (1958). 
to the balancing analysis that takes place in the field of conflict of laws. Under the jurisdictional rule of reason, a nation must weigh a number of factors before deciding whether its contacts with the conduct under challenge are sufficiently strong to warrant the application of its national law. In addition to analyzing more customary factors such as the nationality of the parties, the location of challenged conduct, the effect of that conduct on U.S. commerce, and the foreseeability of such effects, a court (or enforcement official) is also supposed to weigh broader and sometimes countervailing factors. Those factors might include the degree of conflict with foreign law or policy, the relative significance of effects on other countries, and the availability of foreign remedies. ${ }^{28}$ Obviously, many of these countervailing considerations can be present in the case of an export cartel.

In addition to this shift in the U.S. view on jurisdiction, other softenings of the American position are noticeable. In a 1982 cooperation agreement with the Australian government, the United States appeared to go quite far in accepting a right by that country to regulate its exports through governmentsupervised cartels. ${ }^{29}$ At about the same time, the Justice Department took extraordinary steps to reassure the Japanese government that the legal defense of foreign governmental compulsion could shield its export cartels from American antitrust attack. ${ }^{30}$ And in an amicus curiae brief to the Supreme Court in the Japanese Electronics case, the Justice Department sought to broaden the compulsion defense for export cartels by arguing that a foreign sovereign's formal assertion in litigation that a cartel has been compelled under local law had to be accepted as virtually final by a U.S. antitrust tribunal. ${ }^{31}$

28. E.g., Mannington Mills, Inc. v. Congoleum Corp., 595 F.2d 1287, 1297-98 (3d Cir. 1979); Timberlane Lumber Co. v. Bank of Am., 549 F.2d 597, 614 (9th Cir. 1976). The Reagan Administration's newly proposed Foreign Trade Antitrust Improvements Act, S. 2164, 99th Cong., 2d Sess., 132 Cong. Rec. S2288 (daily ed. Mar. 7, 1986), provides a similar although somewhat more limiting listing of factors:

(1) "the relative significance, to the violation alleged, of conduct within the United States as compared to conduct abroad;

(2) "the nationality of the parties and the principal place of business of corporations;

(3) "the presence or absence of a purpose to affect United States consumers or competitors;

(4) "the relative significance and foreseeability of the effects of the conduct on the United States as compared with the effects abroad;

(5) "the existence of reasonable expectations that would be furthered or defeated by the action [i.e., the U.S. antitrust suit]; and

(6) "the degree of conflict with foreign law."

29. Agreement on Antitrust Matters, June 29, 1982, United States-Australia, T.I.A.S. No. 10365, reprinted in 21 INT'L Legal Materials 702 (1982).

30. In this instance the Justice Department's interest was to persuade the Japanese that it could effectively implement government-to-government voluntary restraints on imports into the United States. See Letter from Attorney General William French Smith to United States Trade Representative William E. Brock (Feb. 18, 1981), reprinted in [1969-83 Transfer Binder] Trade Reg. Rep. (CCH) I 50,427 (June 15, 1981); Letter from Attorney General William French Smith to Ambassador Yoshio Okawara of Japan (May 7, 1981), reprinted in 1981-1 Trade Cas. (CCH) 163,998 (May 18, 1981); Applebaum, Antitrust Aspects of Trade Law Cases, 50 AnTitrust L.J. 759, 767-68 (1982).

31. Brief of the United States as Amicus Curiae at 15-27, Matsushita Elec. Indus. Co. v. Zenith Radio Corp., No. 83-2004 (U.S. filed June 17, 1985) (supporting petitioners). 
These shifts in U.S. law were largely the result of a sustained political and diplomatic campaign that has been waged by our trading partners, particularly the United Kingdom, over a period of decades. However, the shifts have far from resolved the international differences, and certainly their present impact can easily be overemphasized. Only recently the Supreme Court observed that "American antitrust laws do not regulate the competitive conditions of other nations' economies," 32 but then the Court quickly reiterated the more classic American position that "when [foreign] conduct has an effect on American commerce" U.S. law will apply. ${ }^{33}$ This was precisely in the context of an antitrust challenge to a foreign export cartel. Similarly, only a few years ago the Justice Department, after consultations with the Commission of the European Communities, broadly hinted that each continent's export cartels were fair game for the other's enforcement agencies. ${ }^{34}$

It is far too early to say that foreign export cartels are immune from American antitrust scrutiny or that jurisdictional disputes with our trading partners are a thing of the past. Compared with a decade ago, however, U.S. law appears to be more flexible and more questioning of why the American antitrust arsenals should be directed against foreign combinations.

\section{Resolving JuRisdictional Conflicts}

Recognizing that serious problems remain, the shifts in U.S. law just described provide hope for thinking that at least some of the harsh jurisdictional conflicts are things of the past. Indeed, some might say that some sort of informal modus operandi is within reach. Given the renewed interest of the United States in its own export cartels, as reflected in the 1982 Export Trading Company Act legislation, and its greater tolerance of foreign export cartels, would it not be possible for U.S. and foreign officials to agree not to sue each other's export cartels? Surely the United States would want to ensure this protection for its own citizens who have invoked the protections of the 1982 legislation, and such an approach would be consistent with the increasingly strong signals the United States has been sending to the effect that it will not aggressively sue the export cartels of others.

The issues, however, are not that simple. One missing element in this proposal is that the United States apparently has not seriously sought to discourage foreign legal attacks on its U.S. export cartels. Indeed, almost the reverse is true. The issue was presented to the United States Government a few years ago when the European Economic Community challenged a U.S.

32. Matsushita Elec. Indus. Co. v. Zenith Radio Corp., 106 S.Ct. 1348, 1354 (1986).

33. Id. at 1354 n.6.

34. See U.S.-EC Consultations on the EC's Proceedings Against Wood Pulp Producers (U.S. Dep't of Justice Press Release), quoted in Stark, A V'iew' of Current International Antitrust Issues (May 20. 1982) (speech by the Chief, Foreign Commerce Section, Antitrust Division, U.S. Dep't of Justice, before a World Trade Institute Seminar) [hereinafter Press Release]. See also Baxter, Antitrust in an Interdependent World 10-11 (Sept. 29, 1981) (speech by the then Assistant Attorney General, Antitrust Division, U.S. Dep't of Justice, to the ABA International Law Section). 
Webb-Pomerene association for price fixing. The United States not only declined to protest, but virtually endorsed the Europeans' suit. ${ }^{35}$ Similarly, in passing the Export Trading Company Act, Congress indicated no intention to discourage foreign antitrust authorities from scrutinizing U.S. industry collaborative efforts. As the House report stated:

[The bill] in no way limits the ability of a foreign sovereign to act under its own laws against an American-based export cartel having unlawful effects in its territory. Indeed, the clarified reach of our own laws could encourage our trading partners to take more effective steps to protect competition in their markets. ${ }^{36}$

Carrying through on this point, in every certificate of review issued under the 1982 legislation the Commerce and Justice Departments have stated explicitly that the certificate constitutes no official endorsement of the certified conduct and confers no immunity under foreign law. ${ }^{37}$ In other words, an American-style export trading company is fair game for foreign antitrust authorities. ${ }^{38}$

Why has the United States Government taken this position, particularly in the face of the shifts of the U.S. enforcement stance described earlier? Unquestionably there is continued skepticism-despite official enthusiasm for the Export Trading Company Act-that, in the end, U.S. export cartels are not likely to be important for our nation's economic well-being or even for our balance of trade. That skepticism may be valid. More importantly, however, the U.S. position also unquestionably reflects an unwillingness by American enforcement officials to take any action that would estop the United States from being able to challenge the export cartels of others. Here, the time for some rethinking has come.

It is submitted that the United States should openly accept the proposition that, in defined circumstances and not simply under a jurisdictional rule of reason, U.S. antitrust laws should not be used to challenge the export cartels of other countries. Those defined circumstances can be stated simply. First, the export cartel should be national rather than international (that is, that it include only producers from within a single country's territory). Second, the cartel should be publicly registered under some statutory program comparable to the Webb-Pomerene or Export Trading Company Acts. Third, the cartel should confine its collaborative behavior strictly to the territory of

35. See Press Release, supra note 34 . The case is now pending in the European Court of Justice.

36. H.R. ReP. No. 686, 97th Cong., 2d Sess. 13-14 (1982). The committee report cited testimony by this author to the effect that the legislation would serve to clarify the allocation of enforcement responsibility between importing and exporting countries; it would not, however, immunize export conduct from all antitrust scrutiny. Hearings on H.R. 2326 Before the Subcomm. on Monopolies and Commercial Law of the House Comm. on the Judiciary. 97th Cong., 1st Sess. 92-94 (1981) (statement of James R. Atwood).

37. E.g., Export Trade Certificate of Review for Crosby Trading Co., at 4 (Nov. 29, 1984) (Application No. A0002), summarized in 49 Fed. Reg. 47,519 (1984).

38. There may have been a brief period when the Justice Department informally took the position that it would not challenge foreign export cartels that were acting in effect as the reciprocal vehicles of Webb-Pomerene associations, but that policy was short lived. See Davidow, Cartels, Competition Law and the Regulation of International Trade, 15 N.Y.U. J. INT'L L. \& PoL. 35I, 363-64 (1983). 
the foreign country in question. For the United States to adopt such a position might seem revolutionary when contrasted with its legal rhetoric of a decade or so ago. But it seems inevitable that the United States is heading in this direction. Such a move would add clarity to the law, reduce the potential for jurisdictional conflicts, and help legitimate American enforcement efforts against cartels that fail to adhere to the described safe-harbor conditions.

The rule of abstention just described follows quite readily from Justice Powell's recent observation in the Japanese Electronics case that the "American antitrust laws do not regulate the competitive conditions of other nations' economies." "39 Surely each nation has the sovereign right to structure or restructure its domestic industries as it sees fit, subject only to certain international legal obligations (unrelated to antitrust) involving norms governing expropriations, national treatment for foreign business, and the like. But if France decided to rationalize its wine industry, or England its Scotch industry, or Canada its lumber industry, most would agree that U.S. antitrust laws properly have nothing to say about such action.

Why might export cartels be different? Of course, by definition export cartels are directed peculiarly at foreign markets. Whereas a general industrial restructuring presumably affects domestic and export markets indiscriminately (in fact, whether that is true depends on the particular products and markets involved), export cartels can be said to discriminate against foreign markets. This undoubtedly lends some legitimacy to an importing country, which seeks to be protected against abusive behavior, to apply its law to the cartel. Also, admittedly there is a degree of awkwardness in a country's insisting on the right to coordinate its companies' export sales where that same country insists on a different industrial structure when it comes to its domestic markets.

Each of these arguments, however, proves too much. The United States now accepts that a simple effect on its markets, standing alone, does not establish a basis for asserting antitrust jurisdiction; a more complex balancing test must be satisfied. And in countless ways-not simply by enactment of the Webb-Pomerene and Export Trading Company Acts-the United States has accepted that foreign trade and domestic trade may require different rules, restrictions, protection of national interests, and the like. The United StatesAustralia agreement ${ }^{40}$ was correct in recognizing that each country has important and legitimate sovereign interests in the exportation of its natural resources or of goods manufactured or produced within its borders. What was implied by that agreement should be adopted by the United States on a broader and more open basis: Disputes over the activities of government sanctioned export cartels should be addressed on a government-to-

39. See supra note 32 .

40. See supra note 29. 
government basis rather than through litigation in national courts under national rules. ${ }^{41}$

The requirement that export cartels be publicly registered under an appropriate national law provides an important element of transparency and an opportunity for government-to-government discussions, if desired.42 It also provides some assurance that the cartel exists and is conducting its operation in conformity with the laws and policies of the local government, an important factor in the rule-of-reason approach to jurisdiction. ${ }^{43}$ Of course, one could go further and require that the export cartel be mandated under foreign law. ${ }^{44}$ This would establish an absolute defense under U.S. law by way of the foreign compulsion doctrine. ${ }^{45}$ But why-in effect-require foreign governments to adopt compulsory cartel-forcing legislation, where the likely effect would be a continuation of the same conduct but with added rigidity and permanence? Also, the more lenient approach of simple registration goes part way at least in meeting foreign governments' complaints that the U.S. compulsion defense currently interferes with the manner in which they wish to govern under their own internal laws and policies. ${ }^{46}$

If a cartel takes on an international as opposed to purely national character, the justification for antitrust abstention becomes less clear. First, a cartel with multinational membership is likely to impose greater damage on the importing state, strengthening that state's interest in taking whatever countermeasures it can. Second, arguments based on the right of a state to nationalize its own industries and on the foreign compulsion defense become more difficult, for trans-border nationalizations and compulsion orders are politically difficult and rare in practice. Thus, an international export cartel should not expect the same deference from U.S. or other antitrust authorities. ${ }^{47}$ For these purposes, however, the European Community should probably be treated as a single national entity.

Neither should an export cartel expect immunity if it engages in restrictive practices outside its national borders. Obviously, for example, every state has the right to regulate price fixing within its own borders, even when the participants have manufacturing facilities or headquarter offices abroad.

41. See Turner, Application of Competition Laws to Foreign Conduct: Appropriate Resolution of Jurisdictional Issues, 26 Swiss Rev. INT'L Competition L. 5, 10-11 (1986).

42. See REPORT OF THE OECD CommitTeE, supra note 5, at 52-53.

43. The "degree of conflict with foreign law or policy" was cited by the courts in both the Timberlane and Mannington Mills cases as the initial issue under their jurisdictional balancing tests. Timberlane Lumber Co. v. Bank of Am., 549 F.2d 597, 614 (9th Cir. 1976); Mannington Mills, Inc. v. Congoleum Corp., 595 F.2d 1287 (3d Cir. 1979). The Administration's new proposal (see supra note 28 ) is narrower, referring only to "the degree of conflict with foreign law." (Emphasis added).

44. See the commentary provided by the Reagan Administration in connection with its proposed Foreign Trade Antitrust Improvements Act of 1986, supra note 28, at 2289.

45. See, e.g., Timberlane Lumber Co. v. Bank of Am., 549 F.2d 597, 606-08 (9th Cir. 1976); InterAmerican Ref. Corp. v. Texaco Maracaibo, Inc., 307 F. Supp. 1291 (D. Del. 1970).

46. See, e.g., Stanford, The Application of the Sherman Act to Conduct Outside the Linited States: A l'iet from Abroad. 11 CoRNELL INT'L L.J. 195, 198, 203-05 (1978).

47. See Turner, supra note 41, at 11-12. 
Thus, if the French winemakers, pursuant to a French approved cartel, wish to agree on an FOB export price in France, that should be permissible. But their marketing arms in the United States cannot meet in New York and discuss how to respond to a proposal by a New York retail chain.

To be sure, none of the rules or conditions that have been suggested will always be clear or self-executing. It is easy to imagine hypothetical situations that would test the skills of any lawyer, judge, or enforcement official. That is inevitable. More importantly, a definitive United States Government statement about its policies towards export cartels can only have so much effect. Private parties would not be bound, and it is the private party suits in recent years that have been the principal source of inter-governmental conflicts. Moreover, many international antitrust controversies-indeed, most-do not involve the sort of pure export cartel discussed.

Nonetheless, every benchmark that can be identified in the field of conflicts of jurisdiction is helpful. Even if it does not resolve too many cases in its immediate context, it provides a frame of reference to help resolve the many cases that will fall between the benchmarks. In a field where at the present the only law that exists is embodied in very broad and general concepts, it is worth striving for a few solid benchmarks.

A final point is that the enforcement stance just described would help legitimize U.S. enforcement efforts against cartels that do not meet the listed criteria. If a cartel engages in restrictive conduct outside the borders of the host country, enlists non-host country members, or acts surreptitiously, the Justice Department would not be bound by a policy of abstention; rather, the Justice Department could argue that the cartel had transgressed reasonable, pre-announced conditions under which it might have escaped suit. In balance, the U.S. authorities would probably have enhanced freedom to attack those cartels that are truly important to U.S. economic interests, and in exchange they would have given up only a rather theoretical right of enforcement against a limited class of cartels where the risks of international discord are greatest.

\section{VI}

\section{ConcLusion}

To avoid any misunderstanding, it should be emphasized that a proliferation of export cartels is not desirable. The relevant issue here, however, is what legal rules a nation should seek to apply to its own export cartels and to those of other nations in today's context of interdependent economies, different national procedures and substantive rules, and proliferating jurisdictional disputes.

There is no easy answer, but for the reasons given the enforcement officials of the United States should retreat from their long-held position of a right to challenge the pure export cartels of other countries. If a cartel is strictly national in competition, publicly registered with its home country, and operating wholly within that country, U.S. objections to that cartel should be 
[Vol. 50: No. 3

made through the diplomatic and legal channels established for the resolution of international trade disputes. The United States should not seek to assert antitrust jurisdiction over that cartel's operations. 